\title{
Tawa nan ampek: A traditional Way of healing Measles, Keteguran and other Disorders in West Sumatra
}

\author{
Alexander Stark ${ }^{1}$, Fatan Hamamah Yahaya ${ }^{2}$, Yohan Kurniawan ${ }^{1}$ \\ ${ }^{1}$ Center for Language Studies and Generic Development, Universiti Malaysia Kelantan, Malaysia. \\ ${ }^{2}$ School of Distance Education, Universiti Sains Malaysia, Malaysia. \\ Correspondence: Alexander Stark, Center for Language Studies and Generic Development, Universiti Malaysia Kelantan, \\ 16100 Kota Bharu, Malaysia.
}

Received: March 1, 2016

Accepted: March 16, 2016

Available online: April 5, 2016

doi:10.11114/ijsss.v4i5.1522

URL: http://dx.doi.org/10.11114/ijsss.v4i5.1522

\begin{abstract}
In this paper, the researchers look at the plants which are called tawa nan ampek. These plants are well-known in West Sumatra and are used for the treatment of medical disorders, especially measles and keteguran. In this article, the researchers describe and illustrate how these plants are used and they explain the emic view of the local population in regard to these plants. The description of certain plants and their usage is important as it expands the cultural knowledge in the field of Minangkabau studies.
\end{abstract}

Keywords: West Sumatra, tawa nan ampek, traditional healing

\section{Introduction}

\subsection{Introductory Words}

In West Sumatra, the Minangkabau form the main population. It is the largest matrilineal society in the world. On the other side, the Minangkabau are also strict Muslims. These two contradicting elements intrigued many researchers from around the world (for example Kato, 1982; Sanday, 2002; Simon, 2014). Many anthropologists focused their research on the description and analysis of the social structure, the historical developments and the role of women. In recent years there is a tendency in focusing on the research of emotions (Heider, 2011; Simon, 2014) as the contradicting elements of the society has an impact on emotions.

Only a few researchers looked at the traditional healing system of the Minangkabau society. The most detailed description of the Minangkabau healing system was written by Kleiweg de Zwaan who was a member of a German-Dutch expedition at the beginning of the $20^{\text {th }}$ century. He mentioned the plants of tawa nan ampek although he did not name it in that way (Kleiweg de Zwaan, 1912, p. 279). An article which was published in recent years was written by Lajtai (Lajtai, 2003). He focused on the role of the traditional Minangkabau healer (dukun) and the way he acts. Both researchers stressed that the healing system of West Sumatra is unique and explained the healing methods of the traditional healers. An article which clearly mentions the healing plants of tawa nan ampek was written by Tas'ady et al. (Tas'ady, Fanany, Fanany, 2013). These authors mentioned that tawa nan ampek is well-known in West Sumatra and used within the households (Tas'ady, Fanany, Fanany, 2013, p. 37). However, these researchers did not explain what kind of plants form tawa nan ampek.

In this article, the researchers want to focus on the description of the most important healing plants namely tawa nan ampek. Until now a medical anthropological viewpoint on the Minangkabau culture is rare although it must be assumed that plants play an important role not only for the healing methods but for the culture itself. For example, if we look at the songs of one of the most popular Minangkabau singers Elly Kassim then we could see that she dedicated a song to two of the healing plants which form tawa nan ampek. The song has the title 'sitawa, sidingin' (https://laguminanglamo.wordpress.com/2008/04/04/sitawa-sidingin/ retrieved on February $25^{\text {th }}$, 2016). This paper intends to have a deeper look in the usage of tawa nan ampek in order get a new perspective on how to look at the Minangkabau culture by integrating the field of ethnomedicine.

\subsection{Hypothesis and Objective}

In this article, it will be tried to cover different aspects of the healing plants which are called tawa nan ampek. The main 
objective is to illustrate the usage of these plants and their importance for the culture of West Sumatra. Here the major question is: What is tawa nan ampek? This question should be answered. It should become clear for what purposes the people use this healing combination. Furthermore, it should be shown how these healing plants are used: Healing plants can be eaten, drunk, used as a crème etc. So, one of the objectives is to get an overview of how the plants are used. The meaning of these plants within the Minangkabau culture should be discussed too.

The main hypothesis is that tawa nan ampek plays an important role in the culture of West Sumatra and that a medical anthropological approach which integrates the world view of the people regarding medical disorders could enrich the field of Minangkabau studies. Here it is actually an emic approach that covers the indigenous world view of the people (Scott / Marshall, 2009, p. 213).

\section{Research Method and Research Setting}

The research took place in a village community in the interior of West Sumatra. Three districts of the interior of this province can be considered as the homeland of the Minangkabau culture (Kato, 1982, p. 36). These three areas are Agam, Tanah Datar and Limapuluh Koto. The village where this research took place was located in the district of Limapuluh Koto.

The research followed a combined method which included both quantitative and qualitative approaches. However, the quantitative approach was only useful in order to know for which medical disorder tawa nan ampek can be used. Here the researchers followed the snowball principle which comprised 40 locals. Nonetheless, the major research method for this research was qualitative. It included open-ended interviews and observations which were both recorded with a camera.

\section{Tawa nan ampek and its usage within the village community}

If we look at the term 'tawa nan ampek' then we can see that it consists of three words namely 'tawa' 'nan' and 'ampek'. The word 'tawa' is closely related to the noun 'penawar'. This word is in general used for a medication which helps to lose a poison or a disease (http://kbbi.web.id/tawar retrieved February $21^{\text {st }}, 2016$.) The word 'nan' is a relative pronoun which is a synonym of 'yang' (and means 'that' or 'which') (http://kbbi.web.id/nan retrieved February 21 $1^{\text {st }}, 2016$ ). 'Ampek' is the Minangkabau word for the number 'four'. So we can say that tawa nan ampek are the 'four medications'.

\subsection{Statistics and Data}

The local community was asked what disorders can be treated by tawa nan ampek. The answers were as follows (see Figure 1):

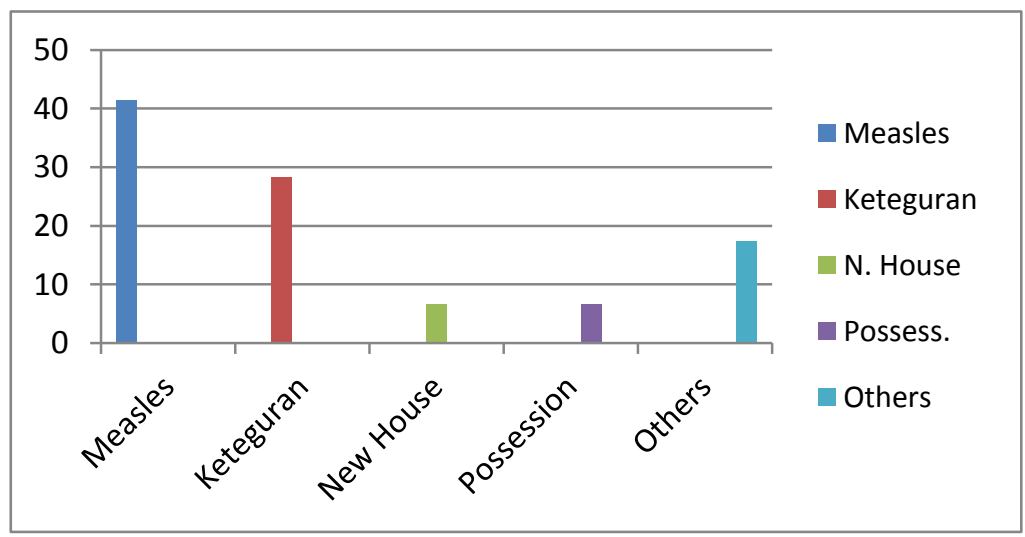

Figure 1. Tawa nan ampek is used for the treatment of these 'disorders'.

In exact numbers the percentage was: Campak (measles) $41.3 \%$, keteguran $28.3 \%$, spirit possession $6.5 \%$, new house $6.5 \%$ and others (like smallpox) 17.4\%. This statistic is quite interesting. The installation of a new house is no sickness at all but the people use tawa nan ampek for 'protection'. One Sufi healer told that tawa nan ampek is very important for the protection and restoration of semangat. The term 'semangat' is very crucial in the Malay-speaking world of Southeast Asia. It is the 'vital principle' (Endicott, 1985, p.49). Nonetheless, the graphic shows clearly that measles and keteguran are the two disorders which are usually treated by tawa nan ampek. Keteguran is a local disorder. The word is derived from the word 'teguran' 'to warn' someone. According to the healer, the patient went to a haunted place and the spirit or jinn of that place gave the person a warning by sending keteguran to him. The symptoms are fever and red dots on the body. These symptoms are quite similar to measles. 


\subsection{The Healing Plants}

The plants of tawa nan ampek have cooling features which will cool the body and strengthen the semangat. In Table 1 the ingredients of tawa nan ampek are listed.

Table 1. The Plants of tawa nan ampek.

\begin{tabular}{|c|c|c|}
\hline Name of the Plants & Photo of the Plants & Usage \\
\hline $\begin{array}{l}\text { Sidingin (Bot. Bryophyllum } \\
\text { Calycinum) }\end{array}$ & & $\begin{array}{l}\text { In the village, the leaves of sidingin } \\
\text { can be used for the treatment of fever. } \\
\text { A leave will be placed on the forehead. }\end{array}$ \\
\hline $\begin{array}{l}\text { Sikarau (some healers call it Cik } \\
\text { Karau) }\end{array}$ & & \\
\hline Sikumpai (Bot. Panicum auritum) & & \\
\hline Sitawa (Bot. Costus Speciosus) & & $\begin{array}{l}\text { In the literature, it is well-known for } \\
\text { the treatment of fever and smallpox } \\
\text { (Ong Hean Chooi, 2006, p.183). Other } \\
\text { authors mentioned that it helps to treat } \\
\text { diarrhea following childbirth (Werner, } \\
2002 \text {, p. 429) }\end{array}$ \\
\hline
\end{tabular}

These four plants form the tawa nan ampek. If someone gets the diagnosis to suffer from measles or keteguran then the treatment with tawa nan ampek is the first choice.

\subsection{The Way to use the Healing Plants}

The healer will collect the four healing plants. Usually, these plants can be found within the village. Some families even domesticate them. Afterwards, the healer chooses three leaves of sidingin and sitawa. Furthermore, he collects three twigs of sikarau and sikumpai. Then these ingredients will be cut into small pieces and put into a pot filled with water (Figure 2). 


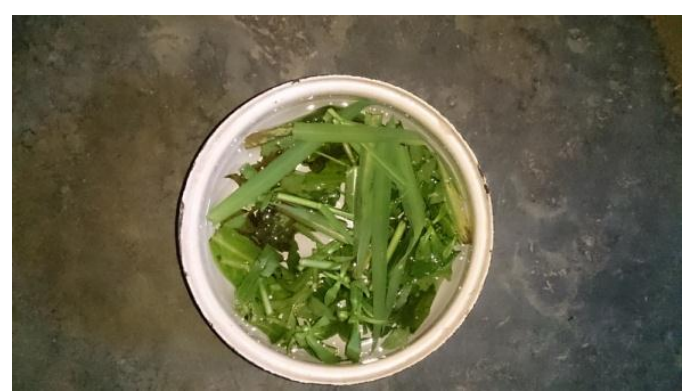

Figure 2. Tawa nan ampek in a pot of water.

After that, the healer looks for a twig of the saliguri plant (Bot.Sida rhombifolia). In the literature it is mentioned that this plant is well-known for rheumatic problems and eczema (Hariana, A., 2002, p. 81). This twig will be dipped into the water. Meanwhile, the patient stands upright with the back faced to the healer. The healer says 'bismillah' (in the name of God) and sprinkles three times the water over the body of the patient. He is doing this by starting from the head towards the feet.

Some healers stressed that it would be preferable if the patient drinks three sips of the water too. The whole healing procedure lasts for three days. During this period, the healer sprinkles two times daily the water on the back of the patient.

\section{Discussion}

The first important finding is that the village people still use traditional healing methods. This is not only the case in the treatment of measles and keteguran but also in the treatment of other medical disorders (for example Stark / Fatan Hamamah Yahaya, 2015).

Tawa nan ampek is a very well-known combination of healing plants. It is said that the plants have the task to cool down the body. For example, if someone gets a fever then the people put a leave of sidingin on the forehead of the patient.

From a cognitive viewpoint, it is obvious that there are two main numbers which play a role namely the number 'four' (the number of plants which are used) and the number 'three' (the treatment lasts for three days, three leaves or twigs are used). Actually, these numbers play a major role within the Minangkabau culture. Karl Heider who made a cognitive research in West Sumatra wrote:

For Minangkabau, four is the dominant pattern number. That means there is a strong tendency to sort things into four categories, or to give four explanations for something. (Heider, 2011, p. 54)

The same is true for the number 'three' (Heider, 2011, p. 55). In this respect, tawa nan ampek is no exception.The number 'four' is very crucial for the understanding of the Minangkabau culture (Ilyas, 2010). If we look at the constitution of the body then we should consider that the body consists of four elements: air, earth, fire and water. The question is whether tawa nan ampek is related to the body. One healer said that the origin of tawa nan ampek is the saliva of Adam. So if we consider this emic point of view then tawa nan ampek is directly related to the first human.

Within the village there are different healing traditions: there is an orthodox Islamic healing way, a Sufi healing tradition and the healing of the traditional healer (dukun). Their healing systems and methods differ. However, all healers stress the importance of tawa nan ampek.

Tawa nan ampek consists of four healing plants and if we look at their names then we can see that there are two words used which are at the beginning of the term namely ' $s i$ ' and ' $c i k$ '. Actually many plant names begin with ' $s i$ ' but if we look at the dictionary the first meaning why someone uses it are as follows:

1 ...article used with names of people...2. article used to emphasize the person who does or is involved in something... (Kelana / Lai Choy, 1998, p. 1368)

It seems that these plants are personified in some way. Some healers prefer the term cik karau which is derived from the term 'Encik' and means 'Mister'. A personified relationship to plants makes the connection between patient and medicinal plants more 'relaxed'. The patient already knows the medication and this can be helpful during the healing process.

\section{Final Remarks}

This article showed that the Minangkabau society uses traditional healing plants. Especially for medical disorders which are not classified by Western biomedicine like keteguran the usage of traditional medicine is useful. Keteguran is 
considered to contain 'hot' features. Therefore, the cooling medication of tawa nan ampek seems to be appropriate. This article showed also that the description of traditional healing plants and healing methods can offer an important contribution to the understanding of the people and their culture. In West Sumatra, it was discovered that the number 'four' plays a crucial cognitive role. It became obvious that for the people there is an unseen world of the spirits that can interfere in the daily life. The people become ill.

It can be concluded that the integration of medical anthropological knowledge can play an important role in the field of Minangkabau studies and it can help to get another point of view.

\section{References}

Balai Bahasa (n.d.). Kamus Besar Bahasa Indonesia. (http://kbbi.web.id, retrieved February $21^{\text {st }}, 2016$ )

Endicott, K. M. (1985). An Analysis of Malay Magic.( $3^{\text {rd }}$ ed.) Singapore / New York: Oxford University Press.

Hariana, A. (2002). Tumbuhan Obat dan Khasiatnya. Seri 3. Depok: Penebar Swadaya.

Heider, K. G. (2011). The Cultural Context of Emotion. Folk Psychology in West Sumatra. New York: Palgrave Macmillan.

Ilyas, A. (2010). Nan Empat. Dialektika, Logika, Sistematika Alam Terkembang. W. P.: Lembaga Kekerabatan Datuk Soda.

Kato, T. (1982). Matriliny and Migration. Evoloving Minangkabau Traditions in Indonesia. Ithaca / London: Cornell University Press.

Kassim, E. \& Syamsi, H. (2008). Sitawa, Sidingin. (https://laguminanglamo.wordpress.com/2008/04/04/sitawa-sidingin/ retrieved on February $25^{\text {th }}, 2016$ )

Kelana, C., \& Lay, C. (1998). Kamus Perwira. Seri Kembangan, Selangor: Penerbitan Daya.

Kleiweg de Zwaan, J. P. (1912). Die Heilkunde der Minangkabauer. In Alfred Maaß (ed.), Durch Zentral-Sumatra. (pp. 13 - 493). Berlin: Verlagsbuchhandlung Wilhelm Süsserot.

Lajtai, L. (2003). A Minangkabau Dukun. Tabula, 6(1), 117-134.

Ong Hean Chooi (2006). Tumbuhan Liar. Khasiat Ubatan \& Kegunaan Lain. Kuala Lumpur: Utusan Publications.

Reenen, J. Van (1996). Central Pillars of the House. Sisters, Wives and Mothers in a rural Community in Minangkabau, West Sumatra. Leiden: Research School CNWS Leiden University.

Sanday, P. R. (2002). Women at the Center. Life in a Modern Matriarchy. Ithaca / London: Cornell University Press.

Scott, J., \& Marshall, G. (2009). A Dictionary of Sociology. New York: Oxford University Press.

Simon, G. M. (2014). Caged in on the outside. Moral subjectivity, selfhood, and Islam in Minangkabau, Indonesia. Honolulu: University of Hawai'i Press.

Stark, A., \& Fatan Hamamah Yahaya (2015). Rongeh: A Skin Disease in West Sumatra: Its Cultural Categories and Traditional Healing Method. American Journal of Humanities and Social Sciences, 3(4), 83-89. http://dx.doi.org/ $10.11634 / 232907811503704$

Tas'ady, R., Fanany, I., \& Fanany, R. (2013). Sickness Ruins the Complexion, Breeding Disappears without Gold. Culture and the Interpretation of Illness among the Minangkabau of West Sumatra, Indonesia. The International Journal of Health, Wellness, and Society, 2(4), 31-41.

Werner, R. (2002). Medicines in Malay villages. Kuala Lumpur: University of Malaya Press.

\section{(cc) $\mathrm{EY}$}

This work is licensed under a Creative Commons Attribution 3.0 License. 